\title{
SENSITIZATION OF PHOTOGRAPHIC EMULSIONS BY COLLOIDAL MATERIALS
}

\author{
By Burt H. Carroll and Donald Hubbard
}

\section{ABSTRACT}

Recent evidence indicates that photographic sensitivity is greatly increased by the presence of ultramicroscopic particles on the silver halide grains of an emulsion. Theories of this effect are discussed in some detail. Technique has been developed by which, without altering other variables, it is possible to introduce colloidal particles into the emulsion to test the possibility that these may be adsorbed by the grains and function as sensitivity nuclei. The experiments were carried out with a number of types of emulsion, including emulsions with the silver halide grains positively charged by adsorption of silver ions. Emulsions of this type were particularly adapted to sensitization by negatively. charged metallic colloids; they were made stable enough for experimental purposes by new technique. The presence of the colloids interfered with afterripening to such an extent that the ultimate effect was desensitization, but the direct result with colloidal gold and silver was an increase in speed at constant or decreased contrast. This may be explained, as proposed by Sheppard, by localization of the photochemical action in the grain around the nucleus, thus increasing developability. The theory that the sensitivity nucleus is a bromine acceptor does not apply to this case. Colloidal silver iodide produced a marked increase in contrast, on chemical development of the emulsion, and in total sensitivity, on physical development. The hypothesis of nucleus exposure which has been used to explain similar results on bathing in iodide solutions can not be applied here; both effects are explained by increased rate of development, probably caused by increased adsorption of the developer.

\section{CONTENTS}

I. Introduction

II. Experimental methods

1. Preparation of the emulsion

2. Methods of testing

III. Sensitization by colloidal silver iodide _._.

IV. Sensitization by colloidal silver

V. Sensitization by silver sulphide _.

VI. Sensitization with colloidal gold _._.

VII. Summary

\section{INTRODUCTION}

The sensitivity of a photographic emulsion is the resultant of its photochemical sensitivity, the chemical change produced by a given exposure, and of the developability of the photochemical change. Either or both of these may be affected by factors which are, over a limited range, nearly independent. These include, for example, the composition of the emulsion in terms of the percentages of the three 
silver halides, the size of the grains, the hydrogen ion concentration, and the presence of nuclei of ultramicroscopic dimensions adsorbed to the grains. The sensitivity as normally measured is a function of all these which defies exact formulation; but in the opinion of the writers, it approaches more nearly a product than a sum. In the case of the faster emulsions, the last-named factor, the nucleus, is perhaps the largest; it is the most generally accepted explanation of the large difference which may exist between emulsions identical except for the origin of the gelatin used in their preparation. This is the result of much indirect evidence, ${ }^{1}$ culminating in the discovery by the Eastman Kodak Laboratories ${ }^{2}$ of sensitizers in gelatin which almost certainly function by reaction with the silver halide to form nuclei of silver sulphide. Prior to Sheppard's publication, the nuclei were considered to be most probably metallic silver, and reasoning both from the conditions in the ripening emulsion and from the action of oxidizing agents on sensitivity, this still accounts for at least part of the nuclei. ${ }^{3}$

The mechanism by which the nucleus acts has been the subject of several hypotheses. In the opinion of the writers, the original mechanism suggested by Sheppard ${ }^{4}$ is the most satisfactory. The essential feature of this is that the nucleus adsorbed to the surface of a silver halide grain produces what may be described as a weak spot in the crystal structure. The photolysis of the silver halide utilizes the entire energy absorbed by the grain, but is localized or oriented to this spot. As a fairly definite minimum size of latent image, is required to start development, the efficiency of the primary photochemical process, from the standpoint of the resulting developed density, is greatly increased if the product is gathered into a single center instead of scattered through the grains in much smaller units. If the material of the sensitivity nucleus is silver, silver sulphide or other substance capable of acting as a development center, the silver from the photolysis of the silver halide will build around it to form the latent image, and the extent of photolysis necessary to produce a latent image of developable size may obviously be much reduced if the sensitivity nucleus was originally but little below this size. The orienting action would not necessarily depend on the composition of the sensitivity nucleus. It might be exerted by a material not in itself capable of acting as a development center. As Toy ${ }^{5}$ has pointed out, the evidence is insufficient for Sheppard's statement that the

1 The following articles are of special importance: Svedberg, Phot. J., 62, p. 186; 1922. Toy, Phil. Mag., 44, p. 352; 1922. Clark, Phot. J., 64, p. 91; 1924. Sheppard, Trivelli, and Loveland, J. Frank. Inst., 200, p. $51 ; 1925$.

2 Sheppard, Phot. J., 65, p. 380; 1925.

${ }^{3}$ Trivelli, J. Frank. Inst., 204, p. 649; 1927. Lüppo-Cramer, Camera, p. 39; 1927. Weigert and Lühr, Naturwissenschaften, 15, p. 788; 1927. Wightman and Quirk., J. Frank. Inst., 204, p. 731; 1927.

4 Sheppard, Trivelli, and Loveland, see footnote 1, above. Sheppard, Brit. J. Phot., 73, p. 33; 1926.

5 Toy, Brit. J. Phot., 73, p. 295; 1926. 
nucleus can not change the quantum efficiency of the primary photolysis.

Hickman ${ }^{6}$ has suggested that silver sulphide may act as an acceptor for the bromine from the photolysis of the silver bromide. Lambert and Wightman ${ }^{7}$ have examined the energy relations and found this possible, even when the reaction is postulated to go to sulphur bromide and metallic silver. On this theory, the failure of halogen absorbents, such as nitrite, to act as sensitizers may be due solely to the fact that they are not adsorbed by the silver halide, and an efficient sensitivity nucleus must be a bromine acceptor. The failure of the adsorption compounds of thiocarbamides and thioanilides ${ }^{8}$ with silver halides to sensitize for anything but the print-out effect, although they are halogen acceptors, is an argument against this theory. This failure of known bromine absorbents to sensitize is supplemented by the success of materials which can not react, with bromine during exposure, such as the metallic silver already mentioned. While it is possible for chemically inert nuclei to adsurb bromine, this is probably unimportant because of their insufficient capacity; the nuclei are of the same order of magnitude as the latent image, and it seems necessary to assume a chemical reaction between the nuclei and the bromine to account for the quantity of the latter which must be absorbed.

Most recently, Trivelli ${ }^{9}$ has proposed a mechanism which combines some of the features of the others with an entirely new idea. He postulates a sensitivity nucleus containing both silver and silver sulphide, which on exposure sets up a photoelectric current from one to the other through the silver bromide, liberating silver from the silver sulphide by electrolysis. The theory derives support from the results of Toy ${ }^{10}$ that the spectral sensitivity of silver bromide is the same for photoconductivity and photographic exposure, and from the improvement in sensitivity by the combined use of the sulphur sensitizers and reducing agents. ${ }^{11}$ If correct, it follows directly that no single material can form an efficient sensitivity nucleus; although in practice silver will almost certainly be present to supplement a second substance. Silver sulphide would be expected to be an exceptionally good sensitizer, according to this theory, since according to Tubandt ${ }^{12}$ it is by a very large factor the best conductor of the solid electrolytic type known. Silver iodide, which is one of the next best, has a conductivity not more than $10^{-3}$ that of the sulphide.

\footnotetext{
${ }^{6}$ Hickman, Phot. J., 67, p. 34; 1927.

${ }^{7}$ Lambert and Wightman, J. Phys. Chem., 31, p. 1249; 1927.

8 Sheppard and Hudson, Phot. J., 67, p. 359; 1927.

${ }^{\circ}$ Trivelli, J. Frank. Inst., 204, p. 849; 1927; 205, p. 111; 1928.

10 Toy, Nature, 120, p. 441; 1927.

11 Sheppard and Punnett, U. S. Patent 1623499.

12 Tubandt and Reinhold, Zeit. anorg. Chem., 160, p. 222; 1927.
} 
Some experiments have already been reported on the effect of colloidal materials on sensitivity. Schwartz and Stock, ${ }^{13}$ following the photolysis of silver bromide by the liberated bromine, found that it could be catalyzed by various colloids, and followed this up by introducing them into completed emulsions. They obtained some increase in sensitivity from Bredig method silver and from a proprietary silica sol (of unknown alkalinity). The metallic colloids in large amounts caused fog. Jenisch ${ }^{14}$ added noble metal sols to the emulsion. Introduced after washing, small amounts had no effect and large amounts caused fog, but when colloidal gold was added to the bromide solution used in mixing the emulsion, the sensitivity was much improved by the use of $3 \mathrm{mg}$. per liter.

The primary object of this investigation was to determine the effect on sensitivity of nuclei adsorbed to the surface of the grains, the nuclei being prepared separately as a colloidal suspension, and introduced into an emulsion which should be reasonably free from ripening nuclei. To be certain that the presence of the nuclei should be the only new factor, they must be added to the emulsion after the end of the ripening, in the sense of change in grain size. Their presence during the mixing or ripening processes, especially the former, might very well change other variables, such as the structure or average size of the grains. An attempt to secure practical improvements in sensitivity by the use of colloids would be very seriously restricted by this condition. The greatest difficulty is the poor adsorptive capacity of the grains in a completed emulsion. Reinders ${ }^{15}$ proved directly that the adsorption of gelatin by silver halides greatly reduces the adsorption of other materials. Some evidence of this had already been obtained from the behavior of emulsions. Lüppo-Cramer found that comparatively large amounts of colloid silver could be added to a completed emulsion with comparatively little effect, but if it were introduced into the original mix it produced intense fog. We succeeded in improving the adsorption, or at least the sensitization, by the use of opposite charges on the colloid particle and emulsion grain, as will be explained in more detail below; but at best only a small part of the colloid introduced is adsorbed. If the colloid used is such that its particles can act as precipitation centers for silver, the unadsorbed excess causes dichroic fog on development if allowed to remain in the emulsion; the dichroic nature of the fog indicates that it is the result of physical development on centers outside the grains. A means for avoiding this difficulty was at hand, in the centrifugal washing of the emulsions, which we ${ }^{16}$ had already used for other purposes. The unadsorbed colloid re-

${ }_{13}$ Schwartz and Stock, Berichte, 54, p. 2111; 1921. Zeit. wiss. Phot., 22, p. 26; 1922.

${ }_{14}$ Jenisch, Zeit, wiss. Phot., 24, p. 248; 1926.

15 Reinders, Zeit. Phys. Chem., 77, p. 677; 1911.

${ }_{16}$ Carroll and Hubbard, J. Phys. Chem., 31, p. 906; 1927. 
mained in the gelatin when the silver halide was centrifuged out, only the portion adsorbed to the grains being carried with them.

The material of the nucleus must be insoluble and not reactive with silver bromide. Silver and silver sulphide are obviously suggested by their occurrence in normally ripened emulsions. Other silver salts less soluble than the bromide and metals more noble than silver also fulfill the necessary conditions. From these classes silver iodide and metallic gold were chosen for serious consideration.

\section{EXPERIMENTAL METHODS}

\section{PREPARATION OF THE EMULSION}

The emulsions were of both ammoniacal and neutral types. Those designated by the series No. 8 were made by the ammonia formula described in the first paper of this series, ${ }^{17}$ using ammonium bromide. The ammoniacal type was found to be more readily sensitized with colloids, as with dyes. The neutral, centrifuged, emulsions have the series No. 6. Their formula was generally as follows, or in the same proportions with increased amounts:

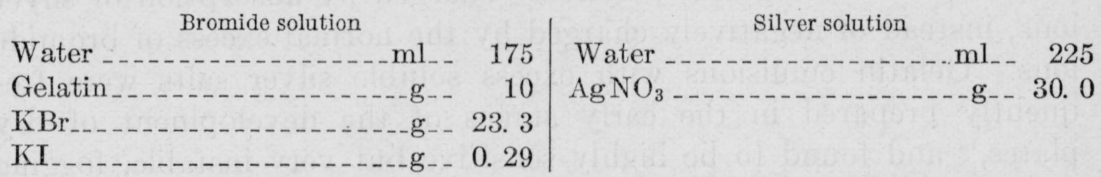

The silver solution was added to the bromide solution very slowly, over a period of 10 to 15 minutes, both solutions being at $65^{\circ} \mathrm{C}$. The emulsion was held at $65^{\circ}$ with stirring until centrifuged, the last batch normally being separated within half an hour from the end of the mixing process. The emulsions of series 1 and 4 were made, respectively, by ammoniacal and neutral formulas identical with those of 8 and 6 , but were washed after the usual chilling and shredding, instead of by the centrifuge. The ripening of these emulsions was limited to a few minutes after the completion of mixing. Swelled gelatin, sufficient to bring the total to $50 \mathrm{~g}$ in a batch of the above size, was then dissolved in the emulsion, which was rapidly chilled, and washed the next day after standing over night at 5 to $8^{\circ} \mathrm{C}$. The $\mathrm{pH}$, after washing 7 hours in Washington tap water, was from 7 to 8. Emulsions of all the series were also made with pure silver bromide, the formula being changed only by substitution of an equivalent amount of bromide for the iodide, without making any obvious difference in the effectiveness of the colloid sensitization, even by colloidal silver iodide.

All the later emulsions were made with deactivated gelatin, to reduce as far as possible the nucleation of the grains before addition

17 Carroll and Hubbard, J. Phys. Chem., 31, p. 906; 1927. 
of the colloid. The method of deactivation which we found most satisfactory for our purposes in these experiments is based on the conversion by ammonia of the isothiocyanates, and probably of more complex sulphur compounds, to the soluble thiocarbamides. After digestion with ammonia (approximately 20 minutes time at $45^{\circ}$ with a normal solution), the gelatin was chilled, shredded, and washed for 24 hours in running water; 12 to 15 hours were necessary for removal of the ammonia so that no Nessler test could be obtained from the drainings. The final $\mathrm{pH}$ of the gelatin varied from 7 to 8 . The physical properties were noticeably injured by the rather drastic ammonia treatment, but no serious difficulty was introduced. The emulsions made with it were slow and very free from fog, but the "after-ripening" (either by digestion or by storage) was not reduced as much as had been anticipated. Expressed in terms of the ratio of speed before and after digestion, it was of the same order as with untreated gelatin.

As a means of improving the adsorption of negatively charged colloids (such as the metals), a large proportion of the emulsions were prepared with the grains positively charged by adsorption of silver ions, instead of negatively charged by the normal excess of bromide ions. Gelatin emulsions with excess soluble silver salts were frequently prepared in the early stages of the development of dry plates, ${ }^{18}$ and found to be highly sensitive but very instable, fogging completely in a few days. This is still not to be considered a practical type of emulsion, but we find that if the hydrogen ion concentration of the emulsion is increased well above the isoelectric point $(\mathrm{pH}$ preferably 3.5 or less), and deactivated gelatin is used, such emulsions may be kept for at least a month without noticeable increase in fog. It is impossible to ripen in the presence of soluble silver salts so the emulsions were made by one or the other of the usual formulas and after the first centrifugal separation, the silver bromide was suspended in acid gelatin, to which silver sulphate was added. After the second centrifuging, the silver bromide was suspended for coating in acid gelatin without further addition of silver sulphate, so that the final excess was limited to that adsorbed on the grains, and was of the same order as the excess soluble bromide in a normal emulsion. The quantities varied slightly, but the following figures are typical:

Excess bromide in the emulsion _...

Silver sulphate added to first suspension _._._._._._._._. g equivalent__ .002

Silver sulphate found in clear gelatin from first resuspension after centri-

fuging out silver bromide_._._._._._. 001

Silver ion concentration in first resuspension $\ldots \ldots \ldots \ldots$

18 Eder, Ausführliches Handbuch der Photographic, 3d ed., 3, p. 50. 
No measurable amount of silver salts could be extracted from the plates coated with these emulsions. The traces of silver sulphate, which must have been present, were evidently adsorbed by the silver bromide. The above use of acid and silver sulphate is implied in the later references in this paper to "emulsions with excess silver." The sensitivity of portions so treated, when compared with other portions of the same emulsion which had been washed and coated at the same $\mathrm{pH}$, but without the addition of silver sulphate, had been at least doubled. However, digestion was impracticable after washing and addition of the silver sulphate; accordingly, the sensitivity produced by the use of the soluble silver salt was less than could be obtained in the same emulsion by after-ripening (by digestion or storage after washing), at the normal $\mathrm{pH}$ of 6 to 8 and in the presence of the usual trace of soluble bromide. The characteristics of these emulsions will be described in more detail in a later paper.

Our regular procedure for washing by the centrifuge is to separate the silver halide from the ripening emulsion, resuspend in dilute gelatin ( $1 \frac{1}{2}$ per cent), separate again, and suspend in the gelatin used for coating. The quantity given in the formula is sufficient for coating four sets of test plates, and the division into the four batches was regularly made in the first resuspension. While both separations are necessary for adequate washing, the concentration of soluble materials in the first resuspension is less than 2 per cent of the value in the unwashed emulsion. The corresponding change in the solubility of silver bromide is still greater, so that ripening, in the sense of change in grain size and structure, may be considered negligible. After-ripening can not be eliminated, but the treatment of the different batches at this stage could be standardized, so that duplicate controls on both types of emulsions were found to check to 10 per cent; the uncertainty thus introduced is thus much smaller than the 50 to 200 per cent changes produced by colloidal sensitization. The capacity of our centrifuge is not sufficient for an entire emulsion at once, but the resuspensions of the two or more portions necessary were carefully mixed. As already mentioned, if the silver sulphate was used, it was added at this point. The emulsion could then be divided into batches identical in concentration, size, ripening, $\mathrm{pH}$, and soluble bromide or silver, to be compared against each other for the sensitizing action of the colloids. The colloids were introduced at this stage of the process. Then, taking care to treat the control and sensitized batches the same, the centrifugal separation was repeated, eliminating the excess colloid. Adsorption of the colloid apparently reached its full value immediately. There was no improvement on allowing it to stand longer than a few minutes before centrifuging. Each batch was suspended for coating in $12.5 \mathrm{~g}$ gelatin in 180 to $220 \mathrm{ml}$ volume, depending on the viscosity. 
Unless stated to the contrary, all emulsions were coated without digestion after washing.- After-ripening is very sensitive to materials adsorbed to the grain, such as color-sensitizing dyes or the colloids. Since digestion involved wide differences in the formation of sensitizing nuclei in the control and colloid-treated batches, it was eliminated as far as possible. The emulsions with excess silver were, of course, liable to fog under digestion treatment perfectly safe for normal emulsions, and could not be after-ripened on this account. The after-ripening in the presence of either dye or colloid is, to the best of our knowledge, invariably less; so much less, as a rule that the control ultimately becomes the faster either on digestion or storage ripening and any after-ripening which occurred before testing tended to subtract from the apparent sensitizing effect of the colloid. No method of sensitization by externally prepared nuclei which we have been able to devise is as efficient as the formation of the nuclei by reaction of the ripened silver halide grains with sensitizers, such as the thiocarbamides.

\section{METHODS OF TESTING}

The standard methods of the Bureau of Standards were used for testing, with modifications of the development to meet certain special cases. Exposure was in all cases on a nonintermittent time scale, at an intensity of one candle meter, of the spectral distribution of mean noon sunlight. The chemical development was by the brush - method, at $20^{\circ}$. The appearance of three times of development $(3,6$, and 12) indicates the usual pyro formula. As the emulsions with excess silver fogged excessively on prolonged development with unbromided pyrogallol, a metol-hydroquinone formula ${ }^{19}$ was used for these. The acid emulsions were particularly sensitive to irregularity of coating. In cases of uncertainty, the 6-minute development was run in quadruplicate.

A considerable number of the emulsions were also compared by physical development, ${ }^{20}$ before, and in some cases, after fixation.

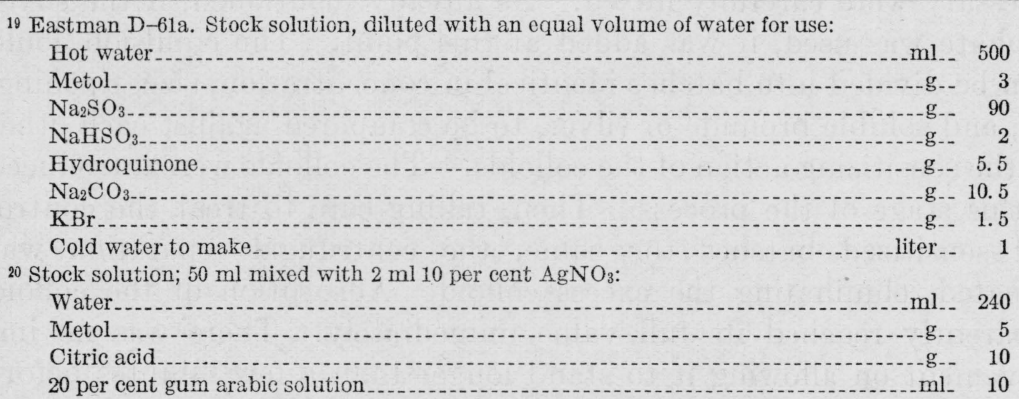

Six minutes development at $15^{\circ}$ or less. Fixation before development in 25 per cent $\mathrm{Na}_{2} \mathrm{~S}_{2} \mathrm{O}_{3}, 5$ per cent. $\mathrm{Na}_{2} \mathrm{SO}_{3}$, followed by 30 minutes washing in running tap water, $\mathrm{pH} 7$ to 8 . 
Physical development of gelatin emulsions is relatively unsatisfactory, but the acid emulsions in this case give less fog than the normal. By comparing only strips which had been developed together, and testing in duplicate or quadruplicate, the results were sufficiently reproducible.

Physical development is commonly regarded as a simple deposition of nascent silver on the nuclei provided by the latent image. It is at least true that the reduction of silver bromide, by a developer such as we used, is negligible, but the physical development is more sensitive than the chemical to adsorption effects which do not appear to involve a change in the amount of latent image. Physical development after fixation should be the most free from complications, but according to Lüppo-Cramer, ${ }^{21}$ bathing with iodide can accelerate development even in this case, indicating that the remaining latent image is not entirely metallic silver. There is the further difficulty that the inertia is invariably much larger for development after fixation than for chemical development, so that it gives no information of conditions at small exposures. Bearing these limitations in mind, physical development is valuable for comparison with the normal method, as will be evident from the results on sensitized emulsions.

One of the principal difficulties of sensitometry became especially obvious in the course of this investigation. The colloid sensitization commonly changed the shape of the characteristic curve, and under these conditions the speed and gamma numbers alone are insufficient for comparison of the sensitivities. The characteristics of the underexposure period (the "toe") are also necessary, but in order to determine then accurately, one must locate more points in the underexposure region than is commonly done. Renwick ${ }^{22}$ has shown that the equation, $D+c=u E$, for the underexposure region, accurately expresses the results up to the beginning of the straight-line portion of the characteristic curve, where it becomes $D=\gamma(\log \mathrm{E}-\log \mathrm{i})$. Designating the exposure at this point by $E_{\mathrm{t}}$, and that for zero density by $E_{0}$, he further derives the equations:

and

$$
E_{\mathrm{t}}=0.434 \gamma / u
$$

$$
E_{\mathrm{t}} / E_{0}=0.434 \gamma / c^{23}
$$

With the limited number of points available in the underexposure region, it is impossible to obtain from our curves the excellent verification of these equations which was found by Renwick. However, the data from the representative curves in Figure 1 will illustrate the points which we wish to make. Referring to Table 1 and the figure,

${ }^{21}$ Lüppo-Cramer, Die Grundlagen der Photographischen Negativverfahren, p. 161.

${ }_{22}$ Renwick, Phot. J., 53, p. 127; 1913.

${ }^{23}$ This becomes indeterminate for $c=0$, since $E_{0}$ then is also 0 . $3696^{\circ}-28-2$ 
it is evident that curves 1 and 4 may be fairly compared on the basis of speed and gamma alone.

TABLE 1

\begin{tabular}{|c|c|c|c|c|c|c|c|c|c|c|}
\hline Emulsion No. . & $\begin{array}{c}\text { Bureau } \\
\text { of } \\
\text { Stand- } \\
\text { ards } \\
\text { speed }\end{array}$ & $\gamma$ & Scale & $c$ & $u$ & $E_{o}$ & $\begin{array}{c}E_{\mathrm{t}} \\
\text { from } \\
D \text {-log } \\
E \text { curve }\end{array}$ & $\begin{array}{c}0.434 \\
\gamma / u\end{array}$ & $\begin{array}{c}E_{t} / E_{0} \\
\text { from } \\
D \text {-log } \\
E \text { curve }\end{array}$ & $\begin{array}{c}0.434 \\
\gamma / c\end{array}$ \\
\hline $\begin{array}{l}6-65-1- \\
6-65-3- \\
6-65-4-4\end{array}$ & $\begin{array}{l}33 \\
11 \\
36\end{array}$ & $\begin{array}{l}0.75 \\
2.00 \\
1.35\end{array}$ & $\begin{array}{r}+10 \\
5 \\
16\end{array}$ & $\begin{array}{l}0.05 \\
.04 \\
.055\end{array}$ & $\begin{array}{l}0.66 \\
.45 \\
1.02\end{array}$ & $\begin{array}{l}0.075 \\
.09 \\
.05\end{array}$ & $\begin{array}{r}1.0 \\
2.5 \\
.8\end{array}$ & $\begin{array}{r}0.5 \\
1.9 \\
.6\end{array}$ & $\begin{array}{l}13 \\
28 \\
16\end{array}$ & $\begin{array}{r}6.5 \\
22.0 \\
11.0\end{array}$ \\
\hline
\end{tabular}

In the case of curves 1 and 3, while one may calculate from these quantities (and the definition, B. S. speed $=10 / i$ ) that the straight

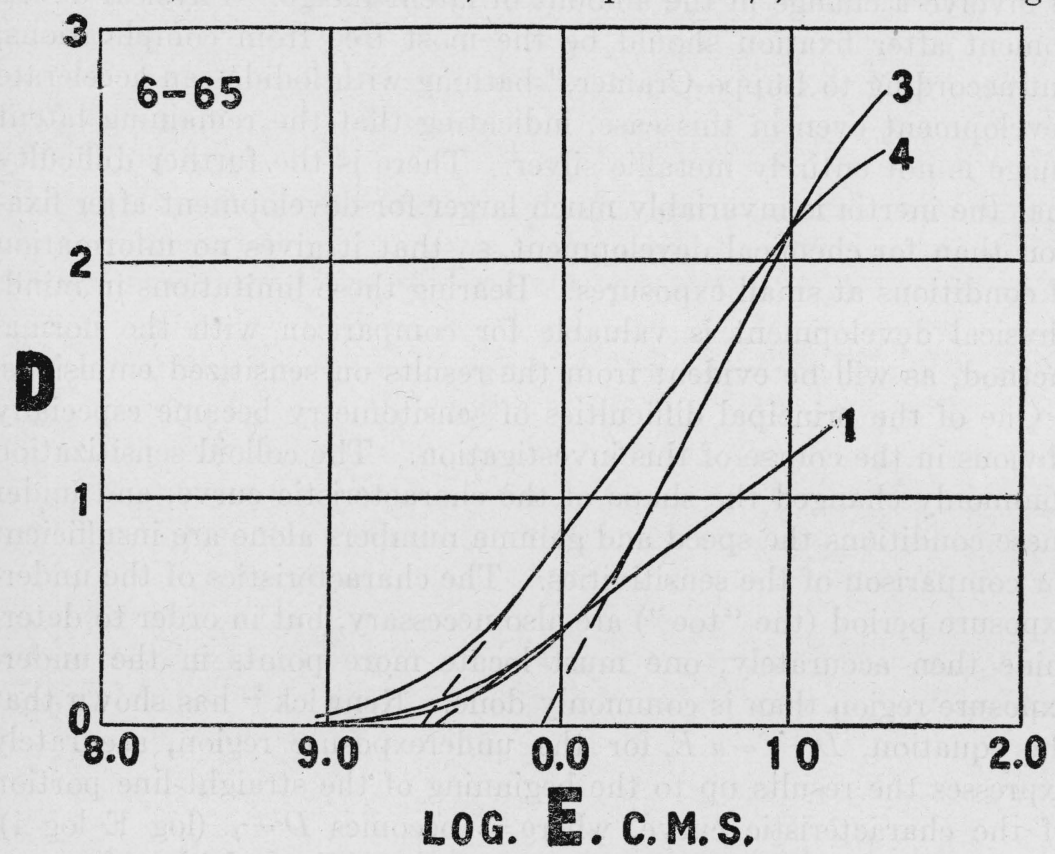

Fig. 1.-Characteristic curves, 12-minute development, for emulsion 6-65

(1) Control; (3) sensitized with colloidal silver iodide; (4) sensitized with colloidal silver

line portions of the curves must cross at $\log E=0.25, D=0.58$, it is impossible to predict that they will practically coincide throughout the underexposure region. There is no theoretical reason why the speed and gamma derived from curve 3 might not be combined with a much larger value of $c$, with correspondingly decreased densities in most of the underexposure region.

We have not made complete determinations of the underexposure characteristics. The characteristic curves, made with a sector wheel of the conventional $H$ and $D$ form, did not regularly include enough points in this region. Enough are given to illustrate the types of change in the underexposure region produced by colloid sensitization. In interpreting the value of $c$ and $u$, it should be remembered that, while $u$ corresponds exactly to $\gamma$ in the equation for the straight line 
portion, it is $c / u$ (or $E_{0}$ ), rather than $c$, which corresponds to $\log i$. Those values of $c$ and $u$ which are given correspond to the longest time of development.

\section{SENSITIZATION BY COLLOIDAL SILVER IODIDE}

The data on this subject have been divided into four sections. Table 2 gives the results with normal emulsions (excess bromide), and Table 3 those with the acid emulsions, with excess silver. Both of these represent immediate tests, without digestion. As most of the emulsions with silver iodide were made before we decided to make use of physical development, some of those which appear for the second time in Table 5, on comparison of the effects with chemical and physical development, had changed considerably by storage ripening since the tests recorded in Table 2 . Since silver iodide alone is not capable of acting as a development center, it may be left in the emulsion without causing fog. A number of such cases are given in Table 4. The iodide was added before digestion, but after the washing was complete, both centrifugal and normal washing having been used. The quantities of silver iodide are in all cases expressed as molar per cent of the total silver halide in the emulsion. The second column of Tables 2, 3, 4, and 5 gives the amount of iodide in the original mix of the emulsion, and, therefore, present before addition of the colloid; the amount of colloidal silver iodide is expressed as " AgI added."

TABLE 2.-Normal emulsions, excess bromide; sensitized with colloidal silver iodide

\begin{tabular}{|c|c|c|c|c|c|c|c|c|c|c|c|c|}
\hline \multirow{2}{*}{$\begin{array}{l}\text { Emul- } \\
\text { sion } \\
\text { No. }\end{array}$} & \multirow{2}{*}{$\begin{array}{l}\text { Mol } \\
\text { per } \\
\text { cent } \\
\text { AgI }\end{array}$} & \multirow{2}{*}{ Type of colloid } & \multirow{2}{*}{$\begin{array}{l}\text { Mol } \\
\text { per } \\
\text { cent } \\
\text { AgI } \\
\text { added }\end{array}$} & \multirow{2}{*}{$\begin{array}{c}\text { Bu- } \\
\text { reau of } \\
\text { Stand- } \\
\text { ards } \\
\text { speed }\end{array}$} & \multicolumn{3}{|c|}{$\gamma$} & \multicolumn{3}{|c|}{ Fog } & & \multirow{2}{*}{$u$} \\
\hline & & & & & 3 & 6 & 12 & 3 & 6 & 12 & & \\
\hline $\begin{array}{r}6-64-1 \\
2 \\
3 \\
4\end{array}$ & 1.5 & $\left\{\begin{array}{l}3 \text { per cent excess } \mathrm{KI} \text {; undialyzed. } \\
3 \text { per cent excess } \mathrm{AgNO}_{3} ; \text { undialyzed. } \\
\text { None. } \mathrm{Ag}_{2} \mathrm{SO}_{4} \text { greater than excess } \\
\mathrm{AgNO}_{3} \text { in colloid. }\end{array}\right.$ & $\begin{array}{l}0.0 \\
1.0 \\
1.0 \\
0\end{array}$ & $\begin{array}{l}56 \\
27 \\
26 \\
72\end{array}$ & $\begin{array}{r}0.30 \\
.63 \\
.64 \\
.20\end{array}$ & $\begin{array}{r}0.45 \\
.80 \\
.72 \\
.38\end{array}$ & $\begin{array}{r}0.50 \\
.90 \\
.78 \\
.44\end{array}$ & $\begin{array}{r}0.12 \\
.31 \\
.21 \\
.10\end{array}$ & $\begin{array}{r}0.22 \\
.36 \\
.30 \\
.18\end{array}$ & $\begin{array}{r}0.28 \\
.44 \\
.34 \\
.21\end{array}$ & $\begin{array}{r}0.04 \\
.01 \\
.04 \\
.03\end{array}$ & $\begin{array}{r}0.86 \\
.42 \\
.38 \\
.75\end{array}$ \\
\hline $\begin{array}{r}3-109-1 \\
4\end{array}$ & 1.0 & Excess $\mathrm{AgNO}_{3}$; dialyzed. & 0 . & $\begin{array}{l}22 \\
19\end{array}$ & $\begin{array}{r}.67 \\
1.10\end{array}$ & $\begin{array}{r}.83 \\
1.42\end{array}$ & $\begin{array}{r}.88 \\
1.60\end{array}$ & $\begin{array}{l}.11 \\
.12\end{array}$ & $\begin{array}{l}.15 \\
.19\end{array}$ & .21 & -- & $-\ldots$ \\
\hline $\begin{array}{r}8-110-1 \\
4\end{array}$ & 1.0 & Equivalent; undialyzed.. & $\left\{\begin{array}{l}0 \\
.\end{array}\right.$ & $\begin{array}{l}18 \\
20\end{array}$ & $\begin{array}{r}.80 \\
1.33\end{array}$ & $\begin{array}{l}1.00 \\
1.85\end{array}$ & $\begin{array}{l}1.10 \\
2.13\end{array}$ & $\begin{array}{l}.10 \\
.17\end{array}$ & $\begin{array}{l}.12 \\
.22\end{array}$ & $\begin{array}{l}.16 \\
.32\end{array}$ & -- & $-\cdots$ \\
\hline $\begin{array}{r}-121-1 \\
2 \\
3\end{array}$ & 1.0 & $\left\{\begin{array}{l}3 \text { per } \\
3 \text { per }\end{array}\right.$ & $\begin{array}{l}0 \\
1.0 \\
1.0\end{array}$ & $\begin{array}{l}17 \\
17 \\
20\end{array}$ & $\begin{array}{l}.80 \\
1.37 \\
1.24\end{array}$ & $\begin{array}{l}1.03 \\
1.60 \\
1.40\end{array}$ & $\begin{array}{l}\text { 1. } 20 \\
\text { 1. } 87 \\
\text { 1. } 60\end{array}$ & $\begin{array}{l}.13 \\
.17 \\
.15\end{array}$ & $\begin{array}{l}.13 \\
.18 \\
.20\end{array}$ & $\begin{array}{l}.23 \\
.24 \\
.25\end{array}$ & $\begin{array}{l}.04 \\
.10 \\
.09\end{array}$ & $\begin{array}{l}.52 \\
.58 \\
.70\end{array}$ \\
\hline & & $\left(\begin{array}{r}\mathrm{Ag}_{2} \mathrm{SO}_{4} \text { equivalent to } 4 \text { times the excess } \\
\mathrm{AgNO}_{3} \text { in colloid. }\end{array}\right.$ & 0 & 27 & .55 & .70 & .85 & .09 & .12 & .16 & .04 & .55 \\
\hline $\begin{array}{r}-123-1 \\
2 \\
3 \\
4\end{array}$ & 1.0 & $\left\{\begin{array}{l}3 \text { per cent excess } \mathrm{KI} ; \text { undialyzed } \\
3 \text { per cent excess } \mathrm{AgNO} \text {; } \text { undialyzed. }_{\text {elloidal } \mathrm{AgI} \text { in the final suspension. }}\end{array}\right.$ & \begin{tabular}{l|}
0 \\
1.0 \\
1.0 \\
.6
\end{tabular} & $\begin{array}{l}20 \\
20 \\
16 \\
17\end{array}$ & $\begin{array}{l}.70 \\
1.05 \\
1.25 \\
1.50\end{array}$ & $\begin{array}{l}.82 \\
1.27 \\
1.50 \\
1.70\end{array}$ & $\begin{array}{r}.96 \\
1.52 \\
1.65 \\
2.13\end{array}$ & $\begin{array}{l}.07 \\
.15 \\
.08 \\
.11\end{array}$ & $\begin{array}{l}.08 \\
.18 \\
.10 \\
.11\end{array}$ & $\begin{array}{l}.13 \\
.25 \\
.17 \\
.20\end{array}$ & $\begin{array}{l}.03 \\
.07 \\
.11 \\
.14\end{array}$ & $\begin{array}{l}.60 \\
.56 \\
.50 \\
.66\end{array}$ \\
\hline $\begin{array}{r}8-125-4 \\
1\end{array}$ & 0 & Equivalent; undialyze & 0 & 20 & & 15 & & $\ldots . .$. & $\begin{array}{l}.11 \\
.36\end{array}$ & & $\begin{array}{l}.09 \\
.05\end{array}$ & $\begin{array}{l}.81 \\
.24\end{array}$ \\
\hline $\begin{array}{r}-961-1 \\
3 \\
6\end{array}$ & .8 & $\left\{\begin{array}{l}5 \text { per cent excess } \mathrm{AgNO}_{3} ; \text { dialyzed. Ex- } \\
\text { posed to diffuse daylight } \\
5 \text { per cent excess } \mathrm{AgNO}_{3} ; \text { dialyzed. } \\
\text { Handled entirely under safe light... }\end{array}\right.$ & .8 & $\begin{array}{l}110 \\
142 \\
147\end{array}$ & $\begin{array}{r}.72 \\
1.20\end{array}$ & 1.82 & 2.10 & $\begin{array}{r}.13 \\
.17 \\
.19\end{array}$ & $\begin{array}{l}.25 \\
.27 \\
.27\end{array}$ & $\begin{array}{r}.44 \\
.39\end{array}$ & $\begin{array}{l}.04 \\
.13 \\
.07\end{array}$ & $\begin{array}{l}3.6 \\
5.4 \\
5.9\end{array}$ \\
\hline
\end{tabular}

${ }_{1}$ All batches of 8-96 digested 30 minutes at $45^{\circ}$ before coating. 
TABLE 3.-Acid emulsions, excess silver; sensitized with colloidal silver iodide

\begin{tabular}{|c|c|c|c|c|c|c|c|c|c|c|c|c|}
\hline \multirow{2}{*}{$\begin{array}{l}\text { Emul- } \\
\text { sion } \\
\text { No. }\end{array}$} & \multirow{2}{*}{$\begin{array}{c}\text { Mol } \\
\text { per } \\
\text { cent } \\
\text { AgI }\end{array}$} & \multirow{2}{*}{ Type of colloid } & \multirow{2}{*}{$\begin{array}{c}\text { Mol } \\
\text { per } \\
\text { cent } \\
\text { AgI } \\
\text { added }\end{array}$} & \multirow{2}{*}{$\begin{array}{c}\text { Bu- } \\
\text { reau of } \\
\text { Stand- } \\
\text { ards } \\
\text { speed }\end{array}$} & \multicolumn{3}{|c|}{$\gamma$} & \multicolumn{3}{|c|}{ Fog } & \multirow{2}{*}{$c$} & \multirow{2}{*}{$u$} \\
\hline & & & & & 3 & 6 & 12 & 3. & 6 & 12 & & \\
\hline $\begin{array}{r}6-60-1 \\
2 \\
3\end{array}$ & 1.0 & $\left\{\begin{array}{l}2 \text { per cent excess } \mathrm{AgN} \mathrm{O}_{3} ; \text { undialyzed. } \\
2 \text { per cent excess } \mathrm{KI} \text {; undialyzed. }\end{array}\right.$ & $\begin{array}{l}0.0 \\
1.1 \\
1.1\end{array}$ & $\begin{array}{l}40 \\
43 \\
34\end{array}$ & $\begin{array}{l}1.46 \\
1.67 \\
1.85\end{array}$ & $\begin{array}{l}1.98 \\
1.86 \\
2.35\end{array}$ & & $\begin{array}{r}0.30 \\
.22 \\
.28\end{array}$ & $\begin{array}{r}0.99 \\
.78 \\
.90\end{array}$ & & $\begin{aligned} 0.181 \\
.141 \\
.121\end{aligned}$ & $\begin{array}{l}\text { 1. } 72 \\
1.70 \\
1.74\end{array}$ \\
\hline $\begin{array}{r}6-65-1 \\
2 \\
3\end{array}$ & 1.5 & $\left\{\begin{array}{l}3 \text { per cent excess } \mathrm{KI} ; \text { undialyzed } \\
3 \text { per cent excess } \mathrm{AgNO}_{3} ; \text { undialyzed. }\end{array}\right.$ & $\begin{array}{l}0 \\
1.0 \\
1.0\end{array}$ & $\begin{array}{l}28 \\
11 \\
13\end{array}$ & $\begin{array}{l}.35 \\
.95 \\
.78\end{array}$ & $\begin{array}{l}.63 \\
1.20 \\
1.50\end{array}$ & $\begin{array}{l}0.75 \\
1.35 \\
2.00\end{array}$ & $\begin{array}{l}.06 \\
.06 \\
.08\end{array}$ & $\begin{array}{l}.11 \\
.11 \\
.18\end{array}$ & $\begin{array}{r}0.22 \\
.24 \\
.37\end{array}$ & $\begin{array}{l}.05 \\
.09 \\
.05\end{array}$ & $\begin{array}{l}.68 \\
.27 \\
.46\end{array}$ \\
\hline $\begin{array}{r}8-111-1 \\
2 \\
3\end{array}$ & 1.0 & $\left\{\begin{array}{l}2 \text { per cent excess } \mathrm{AgNO}_{3} ; \text { undialyzed. } \\
2 \text { per cent excess } \mathrm{KI} \text {; undialyzed. }\end{array}\right.$ & $\begin{array}{l}0 \\
1.1 \\
1.1\end{array}$ & $\begin{array}{l}13 \\
21 \\
12\end{array}$ & $\begin{array}{l}2.40 \\
1.94 \\
2.35\end{array}$ & $\begin{array}{l}\text { 3. } 07 \\
3.10 \\
\text { 3. } 20\end{array}$ & & $\begin{array}{l}.07 \\
.07 \\
.05\end{array}$ & $\begin{array}{l}.18 \\
.17 \\
.18\end{array}$ & & $\begin{array}{l}.23 \\
.23 \\
.28\end{array}$ & $\begin{array}{r}.98 \\
1.24 \\
.81\end{array}$ \\
\hline $\begin{array}{r}8-113-1 \\
6\end{array}$ & 1.0 & $\left\{1\right.$ per cent excess $\mathrm{AgNO}_{3} ;$ undialyzed. & & $\begin{array}{l}23 \\
26\end{array}$ & $\begin{array}{l}1.55 \\
1.37\end{array}$ & $\begin{array}{l}2.54 \\
2.23\end{array}$ & $\ldots$ & .11 & $\begin{array}{l}.29 \\
.32\end{array}$ & $-\cdots$ & .261 & $\begin{array}{l}1.10 \\
1.18\end{array}$ \\
\hline $\begin{array}{r}8-122-1 \\
2 \\
3\end{array}$ & 1.0 & 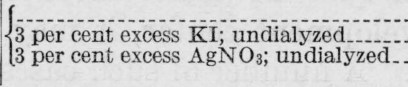 & $\begin{array}{l}0 \\
1.0 \\
1.0\end{array}$ & $\begin{array}{c}6.5 \\
11 \\
9\end{array}$ & $\begin{array}{l}.57 \\
1.10 \\
1.15\end{array}$ & $\begin{array}{l}1.38 \\
2.20 \\
2.30\end{array}$ & $\begin{array}{l}1.98 \\
2.85 \\
3.05\end{array}$ & $\begin{array}{l}.02 \\
.11 \\
.10\end{array}$ & $\begin{array}{l}.11 \\
.15 \\
.14\end{array}$ & $\begin{array}{l}.20 \\
.26 \\
.22\end{array}$ & $\begin{array}{l}.02 \\
.06 \\
.03\end{array}$ & $\begin{array}{l}.21 \\
.27 \\
.20\end{array}$ \\
\hline
\end{tabular}

TABLE 4.-Colloidal silver iodide in final suspension of normal emulsion

\begin{tabular}{|c|c|c|c|c|c|c|c|c|c|c|c|c|}
\hline \multirow{2}{*}{$\begin{array}{l}\text { Emul- } \\
\text { sion } \\
\text { No. }\end{array}$} & \multirow{2}{*}{$\begin{array}{l}\text { Origi- } \\
\text { nal } \\
\text { AgI } \\
\text { in } \\
\text { mol }\end{array}$} & \multirow{2}{*}{$\begin{array}{c}\text { Added } \\
\text { AgI } \\
\text { in mol }\end{array}$} & \multirow{2}{*}{ After ripening } & \multicolumn{3}{|c|}{$\begin{array}{c}\text { 6-minute } \\
M-Q \\
\text { development }\end{array}$} & \multicolumn{3}{|c|}{$\begin{array}{c}\text { Physical } \\
\text { development }\end{array}$} & \multicolumn{3}{|c|}{$\begin{array}{l}\text { Development } \\
\text { after } \\
\text { fixation }\end{array}$} \\
\hline & & & & 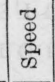 & $>$ & $\begin{array}{l}\infty \\
0 \\
0 \\
x=1\end{array}$ & 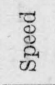 & 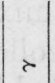 & $\mid \begin{array}{l}\infty \\
0 \\
0 \\
F_{1}\end{array}$ & 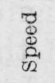 & $\lambda$ & $\sum_{0=1}^{\infty}$ \\
\hline $\begin{array}{r}8-123-1 \\
4 \\
4-25-4 \\
3\end{array}$ & $\left\{\begin{array}{r}P . c t . \\
1.0 \\
.0\end{array}\right.$ & $\left\{\begin{array}{r}P . c t . \\
0.0 \\
.6 \\
.0 \\
.5\end{array}\right.$ & 2 months' storage & $\begin{array}{r}110 \\
47 \\
50 \\
27\end{array}$ & $\begin{array}{l}\text { 1. } 25 \\
\text { 1. } 65 \\
\text { 2. } 07 \\
\text { 2. } 70\end{array}$ & $\begin{array}{r}0.09 \\
.08 \\
.12 \\
.22\end{array}$ & $\begin{array}{r}21 \\
47 \\
9 \\
7\end{array}$ & $\begin{array}{r}0.68 \\
.95 \\
.55 \\
.95\end{array}$ & $\begin{array}{r}0.18 \\
.35 \\
.19 \\
.33\end{array}$ & & $-\cdots-$ & $\mid \cdots$ \\
\hline $\begin{array}{r}1-128-2 \\
5 \\
1-128-6 \\
8\end{array}$ & $\begin{array}{l}.0 \\
.0\end{array}$ & $\begin{array}{l}.0 \\
.5 \\
.0 \\
.5\end{array}$ & Digested 2 hours at $45^{\circ}$ & $\begin{array}{r}45 \\
11 \\
160 \\
30\end{array}$ & $\begin{array}{l}\text { 1. } 45 \\
\text { 2. } 67 \\
\text { 1. } 40 \\
\text { 2. } 00\end{array}$ & $\begin{array}{l}.02 \\
.05 \\
.08 \\
.19\end{array}$ & $\begin{array}{r}7 \\
15 \\
10 \\
17\end{array}$ & $\begin{array}{r}.45 \\
.72 \\
.63 \\
.80\end{array}$ & $\begin{array}{l}.04 \\
.15 \\
.05 \\
.16\end{array}$ & & 等- & \begin{tabular}{l}
$-\cdots$ \\
\hdashline-- \\
\hdashline--
\end{tabular} \\
\hline $\begin{array}{r}1-129-1 \\
2 \\
1-130-1 \\
2\end{array}$ & $\begin{array}{l}.0 \\
.0\end{array}$ & $\left\{\begin{array}{l}.0 \\
.5 \\
.0 \\
.5\end{array}\right.$ & do & $\begin{array}{r}30 \\
18 \\
138 \\
132\end{array}$ & $\begin{array}{l}\text { 2. } 15 \\
\text { 3. } 30 \\
\text { 2. } 10 \\
\text { 2. } 50\end{array}$ & $\begin{array}{l}.03 \\
.03 \\
.15 \\
.20\end{array}$ & $\begin{array}{r}4 . \\
7 . \\
15 \\
43\end{array}$ & $\begin{array}{r}.68 \\
1.30 \\
.98 \\
1.07\end{array}$ & \begin{tabular}{|}
.09 \\
.20 \\
.12 \\
.27
\end{tabular} & $\begin{array}{r}3 . \\
1 . \\
20 \\
17\end{array}$ & $\begin{array}{r}0.27 \\
.48 \\
.28 \\
.38\end{array}$ & $\begin{array}{r}0.46 \\
.48 \\
.35 \\
.34\end{array}$ \\
\hline $\begin{array}{r}1-133-1 \\
2 \\
3\end{array}$ & .0 & $\begin{array}{r}.0 \\
1.5\end{array}$ & do & $\begin{array}{r}174 \\
43 \\
30\end{array}$ & $\begin{array}{l}\text { 1. } 33 \\
\text { 1. } 70 \\
\text { 1. } 62\end{array}$ & $\begin{array}{l}.02 \\
.02 \\
.02\end{array}$ & $\begin{array}{l}12 \\
43 \\
22\end{array}$ & $\begin{array}{l}.60 \\
.55 \\
.58\end{array}$ & $\mid \begin{array}{l}.04 \\
.16 \\
.13\end{array}$ & $\begin{array}{l}45 \\
11 \\
22\end{array}$ & $\begin{array}{l}.15 \\
.27 \\
.18\end{array}$ & $\begin{array}{l}.15 \\
.21 \\
.49\end{array}$ \\
\hline
\end{tabular}

1 The silver iodide in this case was added after digestion was complete. 
TABLE 5.-Comparison of partial conversion to AgI, by bathing in soluble iodide, ${ }^{1}$ with addition of colloidal AgI

\begin{tabular}{|c|c|c|c|c|c|c|c|c|c|c|c|c|c|}
\hline \multirow{2}{*}{$\begin{array}{l}\text { Emul- } \\
\text { sion } \\
\text { No. }\end{array}$} & \multirow{2}{*}{$\begin{array}{c}\text { Origi- } \\
\text { nal } \\
\mathrm{AgI} \\
\text { in } \\
\mathrm{mol}\end{array}$} & \multirow{2}{*}{$\begin{array}{l}\text { Added } \\
\text { AgI } \\
\text { in mol }\end{array}$} & \multirow{2}{*}{$\begin{array}{l}\text { After } \\
\text { ripening }\end{array}$} & \multirow{2}{*}{ Other treatment } & \multicolumn{3}{|c|}{$\begin{array}{c}\text { 6-minute } \\
\text { M-Q } \\
\text { development }\end{array}$} & \multicolumn{3}{|c|}{$\begin{array}{c}\text { Physical } \\
\text { development }\end{array}$} & \multicolumn{3}{|c|}{$\begin{array}{l}\text { Development } \\
\text { after } \\
\text { fixation }\end{array}$} \\
\hline & & & & & 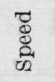 & $\succ$ & $\begin{array}{l}\infty \\
0 \\
1 \times 1\end{array}$ & 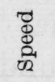 & $\succ$ & $\begin{array}{l}80 \\
0 \\
1 \times 1\end{array}$ & 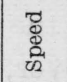 & $\succ$ & $\begin{array}{l}\infty \\
80 \\
0 \\
51\end{array}$ \\
\hline $8-110-1$ & P. ct. & $P . c t$. & 7 months & Washed.... & 166 & 1. 30 & 0.16 & & 0.61 & 10.22 & & 90.25 & 0.43 \\
\hline 1 & 1.0 & & do do... & $\begin{array}{l}\text { Bathed in KI solu- } \\
\text { tion and washed. } \\
\text { Washed. }\end{array}$ & 105 & $\begin{array}{l}1.25 \\
2.30\end{array}$ & $\begin{array}{l}.15 \\
.25\end{array}$ & $\begin{array}{l}43 \\
31\end{array}$ & $\begin{array}{l}.27 \\
.61\end{array}$ & $\begin{array}{l}.23 \\
.35\end{array}$ & 39 & \begin{tabular}{l|l|}
9 & .52 \\
\end{tabular} & .37 \\
\hline $\begin{array}{r}8-109-1 \\
1 \\
4\end{array}$ & 1.0 & .00 & ...do. & $\begin{array}{l}\text { Bathed in KI solu- } \\
\text { tion and washed. } \\
\text { Washed. }\end{array}$ & $\begin{array}{r}190 \\
100 \\
47\end{array}$ & $\begin{array}{l}1.30 \\
1.16 \\
1.61\end{array}$ & $\begin{array}{l}.18 \\
.17 \\
.20\end{array}$ & $\begin{array}{r}25 \\
110 \\
43\end{array}$ & $\begin{array}{l}.60 \\
.21 \\
.55\end{array}$ & $\begin{array}{l}.21 \\
.18 \\
.27\end{array}$ & & $\cdots$ & $-\cdots$ \\
\hline $\begin{array}{r}8-125-4 \\
1 \\
8-123-1\end{array}$ & .0 & $\begin{array}{r}.0 \\
1.0 \\
.0\end{array}$ & $\begin{array}{l}\text { None } \\
\text { do months' }\end{array}$ & None & & $\begin{array}{l}\text { 2. } 15 \\
\text { 5. } 30 \\
\text { 1. } 20\end{array}$ & $\begin{array}{l}.11 \\
.36 \\
.08\end{array}$ & & $\begin{array}{r}.78 \\
1.04 \\
.62\end{array}$ & $\begin{array}{l}.14 \\
.28 \\
.13\end{array}$ & & \begin{tabular}{l|l|}
4 & .23 \\
4 & .50 \\
5 & .30
\end{tabular} & $\begin{array}{l}.52 \\
.49 \\
.44\end{array}$ \\
\hline 2 & .0 & 1. 0 & _._do_. & ...do_. & 63 & 1. 45 & .18 & 39 & .60 & .29 & & 7.37 & .47 \\
\hline $\begin{array}{r}6-64-1 \\
3 \\
\text { Cramer }\end{array}$ & 1.5 & $\begin{array}{r}.0 \\
1.0 \\
.0\end{array}$ & -..do & 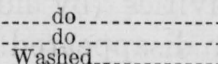 & $\begin{array}{r}145 \\
34 \\
79\end{array}$ & $\begin{array}{l}.84 \\
\text { 1. } 00 \\
2.60\end{array}$ & $\begin{array}{r}.25 \\
.32 \\
10\end{array}$ & $\begin{array}{r}5 \\
22 \\
22\end{array}$ & $\begin{array}{r}.48 \\
.45 \\
1.45\end{array}$ & $\begin{aligned} 8 \\
5.17 \\
5.38 \\
0.08\end{aligned}$ & & \begin{tabular}{l|l|}
6 & .30 \\
0 & .36 \\
3 & .00
\end{tabular} & $\begin{array}{l}.42 \\
.46 \\
.08\end{array}$ \\
\hline Contrast & & 0 & & $\begin{array}{l}\text { Bathed in KI solu- } \\
\text { tion and washed. }\end{array}$ & & 3. 05 & .09 & 45 & .67 & .12 & & 4.74 & .12 \\
\hline
\end{tabular}

1 Four minutes in N/400 KI, followed by 15 minutes washing in running water. The volume of KI solution was such that complete reaction would have converted about 10 per cent of the AgBr to AgI.

Silver iodide may readily be prepared in the colloidal state by reaction of dilute solutions of silver nitrate and potassium iodide. The charge on the particles is negative if an excess of iodide is used, positive if the silver is in excess. ${ }^{24}$ We found it advisable to stabilize all our colloids with gelatin to avoid risk of coagulation on mixing with the emulsion. The silver iodide with excess iodide was made up at approximate neutrality, and that with excess silver at a $\mathrm{pH}$ less than 4.7 , generally at 3.8 , to reduce reaction of the excess silver with the gelatin. N/100 solutions, with 1 per cent gelatin, were rapidly mixed at about $30^{\circ}$. The excess $\mathrm{Ag}^{+}$or $\mathrm{I}^{-}$in undialyzed sols never exceeded 3 per cent. In the absence of protective colloid, the sols with excess iodide are the more stable, corresponding to stronger adsorption of the iodide ion. We found that excess silver was liable to be completely removed by prolonged dialysis of the protected sols, reversing the charge on the silver iodide. Most of the sols were, accordingly, used without dialysis. In the case of the emulsions listed in Table 2, the soluble silver salt introduced along with those silver iodide sols containing excess silver nitrate, was never equivalent to the soluble bromide present in the emulsion at this point. All batches of emulsion listed in this table were coated with excess bromide, with the possible exceptions of 6-64-4 and 8-121-4. Silver

${ }^{24}$ Lottermoser. J. pract. Chem. [2], 75, p. 293; 1907 , 
sulphate only was added to these, and it is evident that its effect was quite different from that of colloidal silver iodide.

The characteristic effect of the colloidal silver iodide was an increase in contrast. Under practical conditions, with digestion of the emulsion after washing, the addition of silver iodide at any point after the original mix of the emulsion produces desensitization. ${ }^{25}$ However, we found by testing the emulsions both with and without after-ripening, that this is explained by the marked tendency of the silver iodide to prevent after-ripening. The immediate effect was to increase the density over most or all of the straight-line portion of the characteristic curve, as compared to the control; the underexposure region was slightly depressed, as a rule. When the iodide was added before the final centrifuging, the speed number was increased and decreased in an equal number of cases; if it was added to the final suspension (with either type of washing), there was an invariable decrease. Either on digestion or storage, the control batches reached higher sensitivities (by normal development), but the difference in gamma never disappeared.

Figure 1 shows the characteristic curves of three batches of 6-65: Control, silver iodide sensitized, and silver sensitized. These illustrate the typical effects of the iodide in increasing density only for the larger values of $E$, and of the metallic colloids, which were most effective at the "toe" of the curve.

All combinations of charge on the silver iodide particles and emulsion grains were tried out, without disclosing the expected improvement by opposite charges. In both types of emulsion the advantage was possibly with the colloid with the same charge as the grains, although the difference was not large enough to be determined with certainty. It is evident that the strong adsorption of silver iodide to silver bromide is specific and is not of the nature of a mutual coagulation of oppositely charged colloids.

The colloidal silver iodide was never exposed to full daylight. This might have affected it, but there was no difference evident between the results with preparations which had been handled only by a safe light, and those which were exposed to the artificial light or weak diffuse daylight of the laboratory. (8-96, Table 2.)

The most striking effect produced by the colloidal silver iodide was the apparent sensitization when the plates were physically developed (Tables 4 and 5). This was accompanied by an increase in fog, which was greater when the excess colloid was not removed by the centrifuge, the average increase being 215 per cent (Table 4) against 87 per cent (Table 5, excluding the bathed plates). The changes in sensitivity and fog both disappeared on development after fixation, within the large limits of error inherent in this method.

${ }^{25}$ Renwick, Sease, and Baldsiefen, Photo. J., 66, p. 163; 1926; also private communication. 
With this evidence, it is possible to account for the results, and we believe that a similar method of attack will be useful in the study of the function of iodide introduced into the emulsion in the original mix.

The acceleration of development by bathing in solutions of soluble iodide, with partial conversion of the silver bromide to silver iodide, has been known for a long time. The results are discussed at length by Lüppo-Cramer. ${ }^{26}$ His hypothesis of nucleus exposure ("Keimblosslegung") is the best known explanation of the phenomena connected with iodide bathing. It may be stated briefly as follows:

Only the nuclei on the surface of the grains are effective in promoting physical development. Those in the interior are relatively ineffective for chemical development, and totally so with the physical developers which do not reduce the grains but supply the silver of the developed image entirely from the solution. Conversion of silver bromide to iodide involves considerable change in volume and crystal structure, and, therefore, disintegrates the silver bromide grains, exposing the nuclei in the interior and making them available as development centers. This theory is apparently well substantiated where extensive conversion to iodide takes place, but Sheppard, Wightman, and Trivelli ${ }^{27}$ have pointed out that the marked selective effects, which are found when very dilute solutions are used, are better explained by increased adsorption of the developer to the iodide. In our experiments, silver iodide was introduced into the emulsion after practically complete removal of soluble bromide, or other silver halide solvents. No replacement of bromine by iodine in the crystal lattice could take place, only adsorption of the silver iodide to the bromide, and the hypothesis of nucleus exposure is therefore inapplicable. The effects of the colloidal silver iodide may be attributed entirely to the acceleration of development. Speed increases even more than contrast, with increasing physical development, so that not only the increased contrast with chemical development, but the increased speed with physical, are accounted for in this way. The increased fog on physical development is logically explained by adsorption of silver nitrate (or a silver nitrate-metol complex). All the silver nitrate in the developer is ultimately reduced, and that adsorbed to the silver iodide in the emulsion produces fog instead of merely a suspension of silver in the developing solution. Fog and silver iodide present increase together in the order-development after fixation, development before fixation of emulsions with the unadsorbed silver iodide eliminated, development before fixation of emulsions with all the silver iodide present.

${ }_{26}$ Lüppo-Cramer, Grundlagen der Photographische Negativverfahren, pp. 526-560.

27 Sheppard, Wightman, and Trivelli, J. Frank. Inst., 196, pp. 653, 779; 1923. 
On the orientation theory of sensitivity nuclei, it might be possible for the adsorption of silver iodide to increase the primary photolysis of silver bromide; in other words, to increase the amount of latent image rather than its developability, but we have obtained no evidence to this effect.

It is not wise to attempt to draw analogies, from the results obtained either by bathing or by addition of colloidal silver iodide, to the use of iodide in the original mix of the emulsion. In the latter case the final product must be largely mixed crystals; while it has been suggested ${ }^{28}$ that adsorption of the developer by iodide may account for the results obtained, there is evidence for a change in the primary sensitivity caused by distortion of the silver bromide crystal lattice on formation of mixed crystals with iodide. ${ }^{29}$ Wilsey ${ }^{30}$ has actually found, by X-ray measurements, the predicted change in the space lattice of (fused) silver bromiodide mixed crystals, and Huse and Meulendyke ${ }^{31}$ find an analogous change in the spectral absorption of the fused salts and in the spectral sensitivity of emulsions of corresponding iodide content.

\section{SENSITIZATION BY COLLOIDAL SILVER}

Metallic silver is one of the probable materials of the sensitivity nuclei, as already mentioned. It is of further interest because it can not be considered as a bromine acceptor. There is no evidence that the photolysis of silver bromide and the bromination of silver reach any equilibrium in light, so that the first process could not be accelerated by the second even in the earliest stages. Bromination after exposure but before development, by local differences of bromine pressure in the grain, would be expected to reduce rather than increase developability, since the bromine would tend to migrate from the interior of the grain to the vital development centers on the surface.

We were able to secure a very definite sensitization by colloidal silver of the acid emulsions with excess soluble silver salts. (Table 6.) The adsorption of the negatively charged metallic colloids on the negatively charged grains of the normal emulsions was apparently too poor for definite results. Gelatin-protected sols gave by far the best sensitization. It was apparently a question of protection rather than particle size, since dextrin-protected sols, which were practically ineffective, were converted by the addition of acidified gelatin into the equivalent of the sols reduced by hydrazine in the presence of gelatin, both in appearance and sensitizing action. The dextrin sols were prepared by the Carey Lea method, with a decreased amount of sodium hydroxide, as suggested by Wiegel..$^{32}$ They were purified by

${ }^{28}$ Sheppard, Phot. J., 62, p. 88; 1922.

${ }_{29}$ Trivelli, Rec. des Trav. Chem. [4], 3, p. 714; 1923.

${ }^{30}$ Wilsey, J. Frank. Inst., 200, p. 739; 1925.

${ }^{21}$ Huse and Meulendyke, Phot. J., 66, p. 306; 1926.

32 Wiegel, Zeit. wiss Phot., 24, p. 316; 1927. 
alcohol precipitation. No difference was apparent between those precipitated once and twice. A number of these sols were treated with hydrochloric acid or sodium chloride, with the idea that, if the adsorbed $\mathrm{OH}^{-}$ions on the particles were replaced by $\mathrm{C1}^{-}$, the adsorption might be improved. There is no evidence that this was of any value. Commercial "argyrol," presumably reduced and protected by hydrolyzed albumen, produced only intense fog without sensitization.

The data in Table 6 are all without after-ripening. The retests in Table 7 were made after two months storage, using both chemical and physical development. The colloid for some reason retarded the reduction of soluble silver salt in the emulsion, since on chemical development the batch with colloid fogged less than the control. The much greater fog on physical development is probably explained by the presence of silver particles large enough to initiate deposition of silver, but not firmly enough adsorbed to accelerate reduction of the silver bromide grains.

There is no evidence in this case of a development effect. The change in sensitivity is primarily a decrease in inertia, with practically constant gamma. The indication is an actual increase in latent image, although it is impossible to decide whether there is a real increase in the photochemical process or only an orientation around silver nuclei.

TABLE 6.-Sensitization with colloidal silver; acid emulsions with excess silver

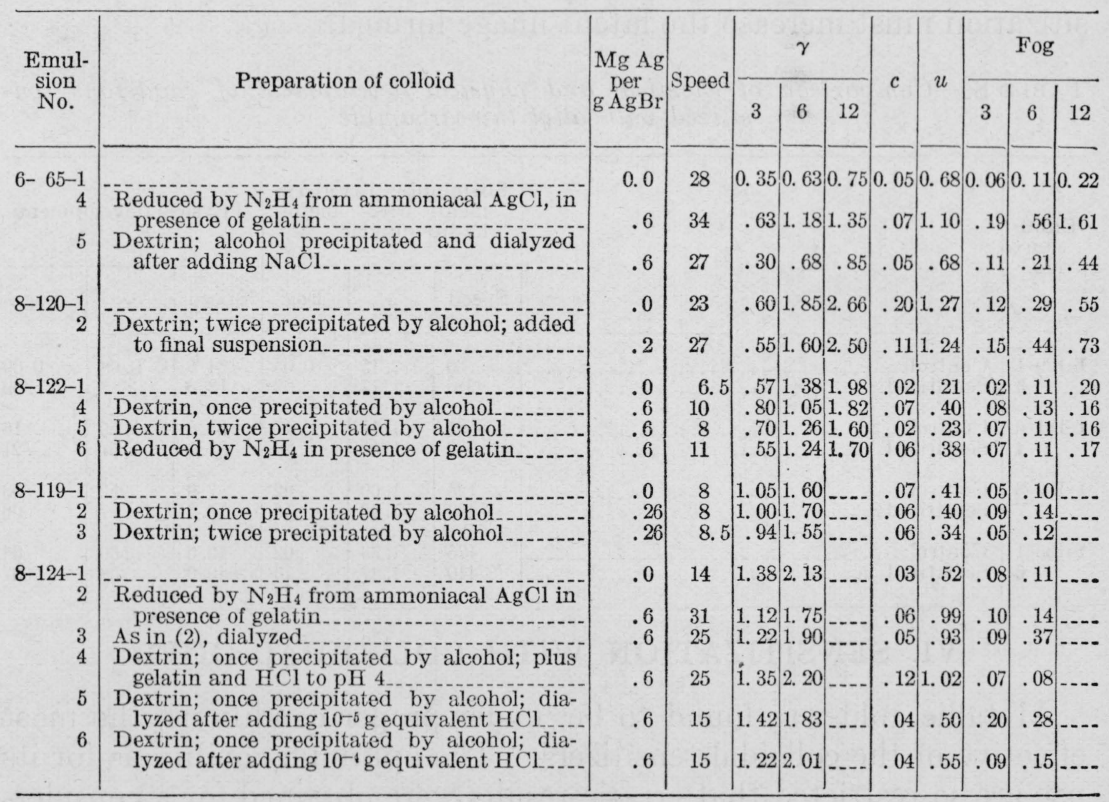


TABLE 7

\begin{tabular}{|c|c|c|c|c|c|c|}
\hline \multirow{2}{*}{ Emulsion No. } & \multicolumn{3}{|c|}{$\begin{array}{l}\text { Six minutes metol-hy- } \\
\text { droquinone develop- } \\
\text { ment }\end{array}$} & \multicolumn{3}{|c|}{ Physical development } \\
\hline & Speed & $\gamma$ & Fog & Speed & $\gamma$ & Fog \\
\hline $6-65-1 \ldots$ & $\begin{array}{r}100 \\
33\end{array}$ & $\begin{array}{l}1.05 \\
1.52\end{array}$ & $\begin{array}{r}0.78 \\
.14\end{array}$ & $\begin{array}{r}10 \\
4\end{array}$ & $\begin{array}{r}0.73 \\
.57\end{array}$ & $\begin{array}{r}0.12 \\
.42\end{array}$ \\
\hline $\begin{array}{r}8-124-1 \\
2\end{array}$ & $\begin{array}{l}47 \\
52\end{array}$ & $\begin{array}{l}2.05 \\
2.05\end{array}$ & $\begin{array}{l}.41 \\
.17\end{array}$ & 9.7 & $\begin{array}{r}1.02 \\
.88\end{array}$ & .08 \\
\hline
\end{tabular}

\section{SENSITIZATION BY SILVER SULPHIDE}

We were unable to produce definite sensitization by colloidal silver sulphide in either type of emulsion. As the silver sulphide caused a considerable increase in fog, it is possible that the particles of the sol were too large. Our sols were prepared by two methods; first, by mixing $0.01 \mathrm{~N}$ solutions of silver nitrate and sodium sulphide, with 1 per cent gelatin in one or both solutions, and second, by the decomposition of silver thiosulphate in the presence of gelatin.

As we wished to compare the results of chemical and physical development on emulsions with silver sulphide nuclei, a number were sensitized with allyl thiocarbamide, 2 to $12 \times 10^{-6} \mathrm{~g} / \mathrm{g}$ of silver bromide. It is evident from the typical cases quoted in Table 8 that the percentage increase in sensitivity is nearly the same by both methods of development. The similarity is so great that a development effect becomes highly improbable. The thiocarbamide sensitization must increase the latent image formed.

TABLE 8-Comparison of chemical and physical development of emulsions sensitized with allyl thiocarbamide

\begin{tabular}{|c|c|c|c|c|c|c|c|}
\hline \multirow{2}{*}{$\begin{array}{l}\text { Emul- } \\
\text { sion } \\
\text { No. }\end{array}$} & & \multicolumn{3}{|c|}{$\begin{array}{l}\text { Six-minute de velop- } \\
\text { ment with metol- } \\
\text { hydro-quinone }\end{array}$} & \multicolumn{3}{|c|}{ Physical development } \\
\hline & & Speed & $\gamma$ & Fog & Speed & $\gamma$ & Fog \\
\hline $\begin{array}{r}1-129-1 \\
3\end{array}$ & $\begin{array}{l}\text { Control } \\
\text { Sensitized_-........ }\end{array}$ & $\begin{array}{r}30 \\
210\end{array}$ & $\begin{array}{l}2.15 \\
1.77\end{array}$ & $\begin{array}{r}0.03 \\
.08\end{array}$ & $\begin{array}{r}4.5 \\
13.0\end{array}$ & $\begin{array}{r}0.68 \\
.88\end{array}$ & $\begin{array}{l}0.09 \\
.09\end{array}$ \\
\hline $\begin{array}{r}1-131-6 \\
4\end{array}$ & $\begin{array}{l}\text { Control } \\
\text { Sensitized... }\end{array}$ & $\begin{array}{r}95 \\
380\end{array}$ & $\begin{array}{l}1.10 \\
1.32\end{array}$ & $\begin{array}{l}.17 \\
.30\end{array}$ & $\begin{array}{l}27.0 \\
87.0\end{array}$ & .50 & .16 \\
\hline $\begin{array}{r}1-132-3 \\
7\end{array}$ & $\begin{array}{l}\text { Control } \\
\text { Sensitized_... }\end{array}$ & $\begin{array}{l}125 \\
480\end{array}$ & $\begin{array}{l}1.60 \\
1.42\end{array}$ & .02 & $\begin{array}{r}7.9 \\
16.0\end{array}$ & .52 & .03 \\
\hline $\begin{array}{r}1-133-1 \\
6\end{array}$ & $\begin{array}{l}\text { Control } \\
\text { Sensitized......... }\end{array}$ & $\begin{array}{l}175 \\
410\end{array}$ & $\begin{array}{l}1.33 \\
1.47\end{array}$ & .02 & $\begin{array}{l}12.0 \\
40.0\end{array}$ & $\begin{array}{l}.60 \\
.58\end{array}$ & .04 \\
\hline
\end{tabular}

\section{SENSITIZATION WITH COLLOIDAL GOLD}

Metallic gold was found to be, under proper conditions, the most effective of the colloidal sensitizers. The optimum conditions for its use are so restricted that erratic results were obtained for a considerable time. They may be summarized as follows: 
The gold sol should be blue to purple in color (absorption maximum about 560 to $570 \mathrm{~m} \mu$ ); free from unreduced auric chloride; free from particles coarse enough to give a cloudy appearance; protected by gelatin.

The emulsion should contain excess silver in a concentration of the order of $2 \times 10^{-3} \mathrm{~N}$ at the time the gold sol is added, and the $\mathrm{pH}$ at this time should be less than 3 (preferably not less than 2); the excess gold and soluble silver should be removed by centrifuging.

Some sensitization of normal emulsions, with excess bromide, is probable, but we were unable regularly to secure effects larger than the experimental error by adding the colloidal gold to the fully ripened and washed emulsion as already described with the other colloids. A number of experiments were also made under other conditions which appeared to have possibility of greater effectiveness. The work of Jenisch ${ }^{33}$ on addition of the gold to the bromide solution used in making the emulsion, was repeated with completely negative results, although we tried both neutral and ammoniacal emulsions with varying degrees of ripening and with three different gold sols. When the gold was added after the mixing was complete, but before washing; it usually caused fog, but the sensitization was within the limits of error. As the presence of the gold under these conditions may alter variables, such as the ripening process, these experiments were discontinued when they did not show promise of practical results.

The necessity of a low pH was entirely unexpected. It is probably connected with the increase in sensitivity of emulsions with excess silver as the $\mathrm{pH}$ of their first resuspension is decreased, an equally unexplained effect, to be treated in a later publication. The data in Table 9 permit direct comparison of sensitization of the same emulsions by the same gold sols at different hydrogen ion concentrations, supported by results with comparable emulsions. The increase in sensitivity at $\mathrm{pH} 2.2$ to 2.5 was 60 to 200 per cent, as compared to 10 per cent or less at $\mathrm{pH} 4.5$ to 5.2. The figures for the underexposure region show that the sensitizing effect of the gold was strongest there; as there was usually a decrease in gamma, it tended to disappear with increasing exposure.

On any of the theories of sensitivity, there should be a minimum effective size for the sensitivity nucleus, and, assuming it to be either a portion of the subsequent development center or a bromine absorbent, the sensitization would, within limits, increase with the size. We made no direct determinations of particle size in the gold sols, but, at least in the case of sols prepared by the same general method, it seems safe to assume that the particle size increases as the spectral absorbtion shifts to the longer wave lengths. We found that a series of sols ranging in color from red through purple to blue may be prepared by

${ }^{33}$ See footnote 14 , p. 568 . 
reduction of auric chloride with hydrazine in the presence of gelatin, varying only the hydrogen ion concentration at the time of reduction. Our results were similar to the much more comprehensive work subsequently published by Beaver and Muller. ${ }^{34}$ As will be evident from inspection of Table 10, the effectiveness of the gold sols increase from almost nothing with the red sols to a maximum with the blue. The regular change in the underexposure regions of 8-113 and 8-115 should be noted. It is peculiar that the neutral emulsions, 6-56 for example, were fogged by the gold more than were the ammoniacal type. The $\mathrm{pH}$ given in the "description of colloid," Table 10 , is that at which reduction of the gold took place; the $\mathrm{pH}$ of the different batches of emulsion was independent of this, and was approximately 3.5 .

All our sols were made up quantitatively with equivalent amounts of standard solutions of auric chloride and bydrazine sulphate, and were generally dialyzed for several days in collodion sacks against distilled water. Undialyzed sols with incomplete reduction (see 8-150-4, Table 11) were generally desensitizing, because of the auric chloride. However, the presence of the gelatin interfered with analysis for possible hydrazine in the sols. Accordingly, hydrazine sulphate was added to the emulsions under the same conditions used for the gold, and was mixed with gold sols on the possibility that the combination might be more effective than either one alone. Large quantities (0.001 mol per mol Ag Br) caused intense fog in the emulsions with excess silver. Smaller amounts, of the order used in preparation of the gold sols, were quite inert, as will be evident from Table 11.

As gold is attacked by the halogens, it might be considered an acceptor for bromine from the photolysis of silver bromide, provided that gold halides are inert to the latent image. Auric chloride solution was found to be destructive to the latent image in high dilutions, as is evident from Table 12. It is even more destructive to sensitivity. There remained the possibility that halogenation may go through the aurous state. Aurous chloride is decomposed by water to gold and auric chloride, and the bromide is less stable. This is, in itself, probably a sufficient argument. However, it is possible to prepare moderately stable solutions of aurous gold ${ }^{35}$ by reduction of auric chloride with sulphite in the presence of soluble chloride. These solutions are almost as destructive to the latent image as those of auric chloride. Because of their unstable nature it was difficult to reproduce results. They occasionally produced heavy fog, accompanied by more than the usual destruction of the latent image, and it was difficult to correlate this with their stability. An illustration of this occurs in the last section of Table 12. These

34 Beaver and Muller, J. Am. Chem. Soc., 50, p. 304; 1928.

${ }_{35}$ Lenher and Diemer, J. Am. Chem. Soc., 35, pp. 546, 552, 733; 1913. 
solutions evidently represent an equilibrium mixture. When sulphite sufficient to reduce the auric chloride to the aurous state is used in the presence of small amounts of soluble chlorides, the yellow color of the solution is not completely discharged, nor is the use of excess sulphite sufficient to do this, but it gradually fades out as the concentration of chloride is increased. It will be noted in the last section of Table 12 that as the molar ratio of $\mathrm{NaCl}$ to $\mathrm{AuCl}$ is raised from 1 to 100, the reduction in density is less, while the addition of more sulphite has no such effect. In fact, it increases the action on the latent image, corresponding possibly to the maximum increase in the electrode potential of gold found by Diemer at the concentration of sulphite corresponding to reduction to $\mathrm{AuCl}$. The evidence is that the actual concentration of aurous ion in these solutions is infinitesimal, as a result of complex formation, and, altogether, that there is no possibility that the bromination of gold either to the aurous or the auric state could assist in the photolysis of silver bromide. We discovered a minor point which is not mentioned by Lenher and Diemer. The aurous solutions are much more stable if neutralized ( $\mathrm{pH} 6$ to 7 ) than if left at the naturally acid reaction of auric chloride solutions. The decomposition in the presence of low concentration of chloride becomes a matter of hours instead of minutes.

Using physical development, the colloidal gold has a marked tendency to cause fog. (Table 9.) Probably because of this there is more often a decrease than an increase in the sensitivity measured this way. With chemical development the unadsorbed gold may be left in the emulsion without causing fog. This is illustrated in Table 13. It is evident that the heavy fog of the gold-sensitized neutral emulsions is not due to unadsorbed excess colloid.

The sensitizing action of collodial gold can not be ascribed to its absorption of bromine or to its ability to act as a development center independent of connection with a silver bromide grain or to its ability to accelerate development. It is uncertain whether a silver-silver bromide-gold photoconductivity cell could be set up or whether its action would increase developability. The theory of an oriented photolysis caused by the adsorption of the gold to the surface of the silver bromide seems to fit the case better than any of the others. 
TABLE 9.-Effect of emulsion $p H$ when colloidal gold was added, on the sensitization produced by the gold

\begin{tabular}{|c|c|c|c|c|c|c|c|c|c|c|c|}
\hline \multirow{2}{*}{$\begin{array}{l}\text { Emul- } \\
\text { sion } \\
\text { No. }\end{array}$} & & \multirow{2}{*}{$\begin{array}{l}\mathrm{pH} \\
\text { at } \\
\text { addi- } \\
\text { tion } \\
\text { of } \\
\text { gold }\end{array}$} & \multirow{2}{*}{$\begin{array}{l}\mathrm{Mg} \\
\mathrm{Au} \\
\text { per g } \\
\mathrm{AgBr}\end{array}$} & \multicolumn{5}{|c|}{$\begin{array}{l}\text { Chemical develop- } \\
\text { ment, } 6 \text { minutes } \\
\text { metol-hydroquinone }\end{array}$} & \multicolumn{3}{|c|}{$\begin{array}{c}\text { Physical } \\
\text { development }\end{array}$} \\
\hline & & & & Speed & $\gamma$ & Fog & $c$ & $u$ & Speed & $\gamma$ & Fog \\
\hline $\begin{array}{r}3-136-1 \\
2 \\
3 \\
4\end{array}$ & dded to first resuspension.- & $\begin{array}{l}5.0 \\
5.0 \\
2.5 \\
2.5\end{array}$ & $\begin{array}{l}0.0 \\
.06 \\
.0 \\
.06\end{array}$ & $\begin{array}{r}4.5 \\
5.0 \\
190.0 \\
350.0\end{array}$ & $\begin{array}{r}2.07 \\
2.35 \\
.83 \\
.80\end{array}$ & $\begin{array}{l}0.05 \\
.09 \\
.21 \\
.48\end{array}$ & $\begin{array}{r}0.00 \\
.00 \\
.00 \\
.00\end{array}$ & $\begin{array}{l}0.32 \\
.32 \\
2.3 \\
4.5\end{array}$ & \begin{tabular}{r|}
2.6 \\
2.7 \\
12.0 \\
20.0
\end{tabular} & $\begin{array}{l}0.73 \\
.72 \\
.57 \\
.50\end{array}$ & $\begin{array}{l}0.02 \\
.10 \\
.02 \\
.05\end{array}$ \\
\hline $\begin{array}{r}8-138-1 \\
2 \\
3 \\
4\end{array}$ & $\begin{array}{l}\text { Control } \\
\text { Gold added to first resuspension } \\
\text { Control } \\
\text { Gold added to first resuspension.... }\end{array}$ & \begin{tabular}{l|}
5.2 \\
5.2 \\
2.2 \\
2.2
\end{tabular} & $\begin{array}{l}.0 \\
.06 \\
.0 \\
.06\end{array}$ & $\begin{array}{r}6.3 \\
6.9 \\
79.0 \\
300.0\end{array}$ & $\begin{array}{r}1.28 \\
1.30 \\
1.00 \\
.79\end{array}$ & $\begin{array}{l}.03 \\
.05 \\
.48 \\
.48\end{array}$ & $\begin{array}{l}.03 \\
.04 \\
.06 \\
.02\end{array}$ & \begin{tabular}{|l|}
.48 \\
.68 \\
1.65 \\
4.4
\end{tabular} & $\begin{array}{r}6.3 \\
2.0 \\
30.0 \\
14.0\end{array}$ & $\begin{array}{l}.60 \\
.61 \\
.51 \\
.50\end{array}$ & $\begin{array}{l}.03 \\
.17 \\
.02 \\
.17\end{array}$ \\
\hline $\begin{array}{r}8-140-3 \\
4\end{array}$ & $\begin{array}{l}\text { Control } \\
\text { Gold added to first resuspension. }\end{array}$ & $\begin{array}{l}2.4 \\
2.4\end{array}$ & $\begin{array}{l}.0 \\
.06\end{array}$ & $\begin{array}{r}230.0 \\
380.0\end{array}$ & $\begin{array}{r}1.00 \\
.72\end{array}$ & $\begin{array}{l}.40 \\
.67\end{array}$ & $\begin{array}{l}.01 \\
.02\end{array}$ & 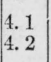 & $\begin{array}{l}27.0 \\
22.0\end{array}$ & $\begin{array}{l}.56 \\
.48\end{array}$ & $\begin{array}{l}.02 \\
.09\end{array}$ \\
\hline $\begin{array}{r}8-150-1 \\
2\end{array}$ & $\begin{array}{l}\text { Control } \\
\text { Gold added to first resuspension. }\end{array}$ & $\begin{array}{l}2.5 \\
2.5\end{array}$ & $\begin{array}{l}.0 \\
.12\end{array}$ & $\begin{array}{r}145.0 \\
230.0\end{array}$ & $\begin{array}{l}.92 \\
.93\end{array}$ & $\begin{array}{l}.17 \\
.31\end{array}$ & & $\begin{array}{l}2.55 \\
5.0\end{array}$ & $\begin{array}{l}11.5 \\
26.0\end{array}$ & $\begin{array}{l}.90 \\
.53\end{array}$ & .09 \\
\hline $\begin{array}{r}8-129-1 \\
2\end{array}$ & $\begin{array}{l}\text { Control } \\
\text { Gold added to first resuspension. }\end{array}$ & $\begin{array}{l}4.5 \\
4.5\end{array}$ & $\begin{array}{l}.0 \\
.12\end{array}$ & $\begin{array}{l}16.0 \\
15.0\end{array}$ & $\begin{array}{l}1.63 \\
1.80\end{array}$ & .05 & $\begin{array}{l}.04 \\
.05\end{array}$ & $\begin{array}{l}.48 \\
.49\end{array}$ & $\begin{array}{l}5.7 \\
3.9\end{array}$ & $\begin{array}{l}.65 \\
.69\end{array}$ & $\begin{array}{l}.04 \\
.17\end{array}$ \\
\hline $\begin{array}{r}8-131-1 \\
3\end{array}$ & $\begin{array}{l}\text { Control } \\
\text { Gold added to first resuspension }\end{array}$ & $\begin{array}{l}5.0 \\
5.0\end{array}$ & $\begin{array}{l}.0 \\
.09\end{array}$ & $\begin{array}{l}11.0 \\
10.5\end{array}$ & $\begin{array}{l}1.45 \\
1.42\end{array}$ & .05 & $\begin{array}{l}.01 \\
.02\end{array}$ & $\begin{array}{l}.52 \\
.68\end{array}$ & $\begin{array}{l}3.3 \\
2.1\end{array}$ & $\begin{array}{l}.95 \\
.96\end{array}$ & $\begin{array}{l}.05 \\
.16\end{array}$ \\
\hline
\end{tabular}

TABLE 10.-Comparison of sensitization by gold sols of varying dispersion

\begin{tabular}{|c|c|c|c|c|c|c|c|c|c|}
\hline \multirow{2}{*}{$\begin{array}{c}\text { Emul- } \\
\text { sion } \\
\text { No. }\end{array}$} & \multirow{2}{*}{ Description of colloid } & \multirow{2}{*}{$\begin{array}{c}\mathrm{Mg} \\
\mathrm{Au} \\
\text { perg } \\
\mathrm{AgBr}\end{array}$} & \multirow{2}{*}{ Speed } & \multicolumn{2}{|c|}{$\gamma$} & \multirow{2}{*}{$c$} & \multirow{2}{*}{$u$} & \multicolumn{2}{|c|}{ Fog. } \\
\hline & & & & 3 & 6 & & & 3 & 6 \\
\hline \multirow{3}{*}{$\begin{array}{r}6-56-1 \\
4\end{array}$} & Control_ & 0.0 & 64 & 0.20 & 0.80 & 0.09 & 1. 06 & 0.03 & 0.35 \\
\hline & $\begin{array}{l}\text { Reduced by } \mathrm{N}_{2} \mathrm{H}_{4} \text { in presence of gelatin. } \\
\text { Blue }\end{array}$ & .2 & 103 & .50 & .83 & .04 & 2. 60 & 1.03 & 2. 23 \\
\hline & $\begin{array}{l}\text { Reduced by НСНО, without protection. } \\
\text { Red. }\end{array}$ & .2 & & & & .11 & 1.40 & .28 & .72 \\
\hline \multirow{2}{*}{$\begin{array}{r}8-113-1 \\
2\end{array}$} & Control & .0 & 23 & 1.55 & 2. 54 & .25 & 1. 10 & .11 & .29 \\
\hline & $\begin{array}{l}\text { Reduced by } \mathrm{N}_{2} \mathrm{H}_{4} \text { in presence of } 0.1 \text { per } \\
\text { cent gelatin; } \mathrm{pH} 3.5 \text {. Orange }\end{array}$ & .2 & 23 & 1.60 & 2.45 & .23 & 1.18 & .15 & .34 \\
\hline 3 & $\begin{array}{l}\text { Reduced by } \mathrm{N}_{2} \mathrm{H}_{4} \text { in presence of } 0.1 \text { per } \\
\text { cent gelatin; pH } 8.2 \text {. Purple }\end{array}$ & .2 & 35 & 1.48 & 1.93 & .20 & 1.50 & .17 & .40 \\
\hline 4 & $\begin{array}{l}\text { Reduced by } \mathrm{N}_{2} \mathrm{H}_{4} \text { in presence of } 0.05 \text { per } \\
\text { cent gelatin; } \mathrm{pH} 8.5 \text {. Blue }\end{array}$ & & 00 & 1.1 & 2 & & 200 & F & 1.0 \\
\hline \multirow[t]{2}{*}{5} & Reduced by $\mathrm{N}_{2} \mathrm{H}_{4}$ in presence of 0.025 per & & & & & & & & \\
\hline & ce & 2 & 48 & 1.65 & 2.10 & .28 & 2. 55 & .19 & .50 \\
\hline \multirow{2}{*}{$\begin{array}{r}8-115-1 \\
2\end{array}$} & Control & .0 & 21 & 1.62 & 2. 37 & .12 & 1.05 & .10 & .16 \\
\hline & $\begin{array}{l}\text { Reduced by } \mathrm{N}_{2} \mathrm{H}_{4} \text { in presence of } 0.1 \text { per } \\
\text { cent gelatin; } \mathrm{pH} 3.5 \text {. Orange }\end{array}$ & 2 & 14 & 1.70 & 2.60 & 10 & 72 & 13 & 23 \\
\hline 3 & Reduced by $\mathrm{N}_{2} \mathrm{H}_{4}$ in presence of 0.1 per & & $2 x$ & 10.0 & 2.00 & 06 & 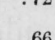 & 100 & .200 \\
\hline & & & & & & & & & \\
\hline
\end{tabular}


TABLE 11.-Test for sensitization by hydrazine; comparison of dialyzed and undialyzed gold sols

\begin{tabular}{|c|c|c|c|c|c|c|c|c|c|c|}
\hline \multirow[t]{2}{*}{$\begin{array}{l}\text { Emul- } \\
\text { sion } \\
\text { No. }\end{array}$} & \multirow{2}{*}{$\begin{array}{l}\mathrm{pH} \text { when } \\
\mathrm{N}_{2} \mathrm{H}_{4}-\mathrm{H}_{2} \mathrm{SO}_{4} \\
\text { or gold was } \\
\text { added }\end{array}$} & \multirow{2}{*}{ 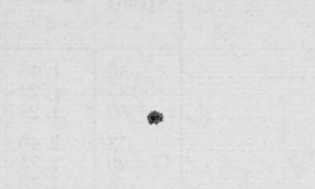 } & \multirow[t]{2}{*}{$\begin{array}{l}\mathrm{MgAu} \\
\text { perg } \\
\mathrm{AgBr}\end{array}$} & \multirow{2}{*}{$\begin{array}{c}\mathrm{Mol} \\
\mathrm{N}_{2} \mathrm{H}_{4-}^{-} \\
\mathrm{H}_{2} \mathrm{SO}_{4} \\
\text { per mol } \\
\mathrm{AgBr}\end{array}$} & \multicolumn{3}{|c|}{$\begin{array}{c}\text { Chemical } \\
\text { development } \\
\text { 6-minute } \\
\text { metol- } \\
\text { hydroquinone }\end{array}$} & \multicolumn{3}{|c|}{$\begin{array}{c}\text { Physical } \\
\text { development }\end{array}$} \\
\hline & & & & & speed & $\gamma$ & Fog & Speed & $\gamma$ & Fog \\
\hline $\begin{array}{r}8-128-1 \\
3 \\
4\end{array}$ & Same as & $\begin{array}{l}\text { Control } \\
\text { Undialyzed blue gold by } \mathrm{N}_{2} \mathrm{H}_{4} \\
\text { Same gold as in (3) dialyzed.. }\end{array}$ & $\begin{array}{l}0.0 \\
.12 \\
.12\end{array}$ & 0.0 & $\begin{array}{l}20.0 \\
25.0 \\
25.0\end{array}$ & $\begin{array}{l}1.65 \\
1.53 \\
1.85\end{array}$ & $\begin{array}{l}0.06 \\
.66 \\
.12\end{array}$ & $\begin{array}{l}7.9 \\
4.3 \\
4.5\end{array}$ & $\begin{array}{r}0.54 \\
.82 \\
.78\end{array}$ & $\begin{array}{l}0.04 \\
.23 \\
.16\end{array}$ \\
\hline $\begin{array}{r}8-130-1 \\
2 \\
3 \\
6\end{array}$ & 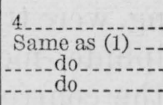 & $\begin{array}{l}\text { Control } \\
\text { Hydrazine only } \\
\text { Hydrazine only } \\
\text { Dialyzed blue gold by } \mathrm{N}_{2} \mathrm{H}_{4-}\end{array}$ & $\begin{array}{l}.0 \\
.0 \\
.0 \\
.12\end{array}$ & $\begin{array}{l}0.0 \\
1.6 \times 10^{-5} \\
1.6 \times 10^{-6} \\
0.0\end{array}$ & $\begin{array}{l}12.0 \\
12.6 \\
12.6 \\
17.4\end{array}$ & $\begin{array}{l}1.37 \\
1.40 \\
1.43 \\
1.30\end{array}$ & $\begin{array}{l}.09 \\
.09 \\
.08 \\
.13\end{array}$ & $\begin{array}{l}4.5 \\
5.0 \\
5.5 \\
4.7\end{array}$ & $\begin{array}{l}.40 \\
.38 \\
.31 \\
.28\end{array}$ & $\begin{array}{l}.03 \\
.03 \\
.02 \\
.15\end{array}$ \\
\hline $\begin{array}{r}8-133-1 \\
2 \\
3 \\
4\end{array}$ & $\begin{array}{l}4-1 \\
\text { Same a } \\
-\ldots \text { do } \\
-\end{array}$ & $\begin{array}{l}\text { Control } \\
\text { Dial yzed blue gold by } \mathrm{N}_{2} \mathrm{H}_{4-} \\
\text { Hydrazine only } \\
\text { Same gold as in (2), plus } \\
\mathrm{N}_{2} \mathrm{H}_{4}-\mathrm{H}_{2} \mathrm{SO}_{4} \text {. }\end{array}$ & $\begin{array}{l}.0 \\
.06 \\
.0 \\
.06\end{array}$ & $\begin{array}{l}0.0 \\
0.0 \\
3.3 \times 10^{-5} \\
3.3 \times 10^{-5}\end{array}$ & $\begin{array}{l}\text { 17. } 01 \\
20.01 \\
18.01 \\
16.01\end{array}$ & $\begin{array}{l}\text { 1. } 30 \\
\text { 1. } 23 \\
\text { 1. } 23 \\
1.26\end{array}$ & $\begin{array}{l}.08 \\
.08 \\
.07 \\
.08\end{array}$ & $\begin{array}{l}2.5 \\
2.5 \\
2.5 \\
2.4\end{array}$ & $\begin{array}{l}.60 \\
.58 \\
.61 \\
.62\end{array}$ & $\begin{array}{l}.04 \\
.06 \\
.04 \\
.08\end{array}$ \\
\hline $\begin{array}{r}8-138-3 \\
.5 \\
4\end{array}$ & $\begin{array}{l}2.2- \\
2.2- \\
2.2-\end{array}$ & $\begin{array}{l}\text { Control } \\
\text { Hydrazine only } \\
\text { Dialyzed purplegold by } \mathrm{N}_{2} \mathrm{H}_{4}\end{array}$ & $\begin{array}{l}.0 \\
.0 \\
.06\end{array}$ & $\begin{array}{l}0.0 \\
\text { 8. } 2 \times 10^{-5} \\
0.0\end{array}$ & $\begin{array}{r}79.01 \\
110.01 \\
300.0\end{array}$ & $\begin{array}{l}1.00 \\
1.08 \\
.79\end{array}$ & $\begin{array}{l}.48 \\
.43 \\
.48\end{array}$ & $\begin{array}{r}30.0 \\
8.0 \\
14.0\end{array}$ & $\begin{array}{l}.51 \\
.53 \\
.50\end{array}$ & $\begin{array}{l}.02 \\
.04 \\
.17\end{array}$ \\
\hline $\begin{array}{r}8-140-1 \\
2 \\
3 \\
4 \\
5\end{array}$ & $\begin{array}{l}5.0- \\
5.0- \\
2.4- \\
2.4- \\
2.4-\end{array}$ & $\begin{array}{l}\text { Control } \\
\text { Hydrazine only } \\
\text { Control } \\
\text { Dialyzed purplegold by } \mathrm{N}_{2} \mathrm{H}_{4} \\
\text { Hydrazine only }\end{array}$ & $\begin{array}{l}.0 \\
.0 \\
.0 \\
.06 \\
.0\end{array}$ & $\begin{array}{l}0.0 \\
\text { 1. } 6 \times 10^{-4} \\
0.0 \\
0.0 \\
1.6 \times 10^{-4}\end{array}$ & $\begin{array}{l}132.0 \\
110.0 \\
230.01 \\
380.0 \\
174.01\end{array}$ & $\begin{array}{r}.36 \\
.36 \\
1.00 \\
.72 \\
1.07\end{array}$ & $\begin{array}{l}.08 \\
.09 \\
.40 \\
.67 \\
.48\end{array}$ & $\begin{array}{r}2.9 \\
5.0 \\
27.0 \\
22.0 \\
25.0\end{array}$ & $\begin{array}{l}.38 \\
.26 \\
.56 \\
.48 \\
.60\end{array}$ & $\begin{array}{l}.02 \\
.02 \\
.02 \\
.09 \\
.02\end{array}$ \\
\hline $\begin{array}{r}8-150-1 \\
2 \\
4\end{array}$ & $\begin{array}{l}2.5- \\
2.5- \\
2.5-\end{array}$ & $\begin{array}{l}\text { Control } \\
\text { Dialyzed blue gold by }{ }_{2} \mathrm{H}_{4-} \\
\text { Undialyzed purple gold by } \\
\mathrm{N}_{2} \mathrm{H}_{4} ; \text { reaction between } \\
\mathrm{AuCl}_{3} \text { and } \mathrm{N}_{2} \mathrm{H}_{4} \text { incom- } \\
\text { plete. }\end{array}$ & $\begin{array}{l}.0 \\
.12 \\
.12\end{array}$ & $\begin{array}{l}0.0 \\
0.0\end{array}$ & $\begin{array}{r}145.0 \\
230.0 \\
75.0\end{array}$ & $\begin{array}{l}.92 \\
.93 \\
.93\end{array}$ & $\begin{array}{l}.17 \\
.30 \\
.18\end{array}$ & $\begin{array}{l}11.5 \\
26.0 \\
14.5\end{array}$ & \begin{tabular}{|l|}
.90 \\
.53 \\
.37
\end{tabular} & $\begin{array}{l}.07 \\
.08 \\
.21\end{array}$ \\
\hline
\end{tabular}

TABLE 12.-Effect of gold chlorides on latent image. Strips exposed in the sensitomeier were bathed in gold chloride solutions, $0.100 \mathrm{~g}$. Au per liter, washed thoroughly and developed without drying. All results average of two strips

\begin{tabular}{l|l|l|r|r|r|r|r|r|r|}
\hline $\begin{array}{c}\text { Emulsion } \\
\text { No. }\end{array}$ & \multicolumn{3}{|c|}{ Solution } \\
\hline
\end{tabular}


TABLE 13.-Colloidal gold added to final suspension of emulsions; blue sols, reduced by hydrazine and gelatin protected

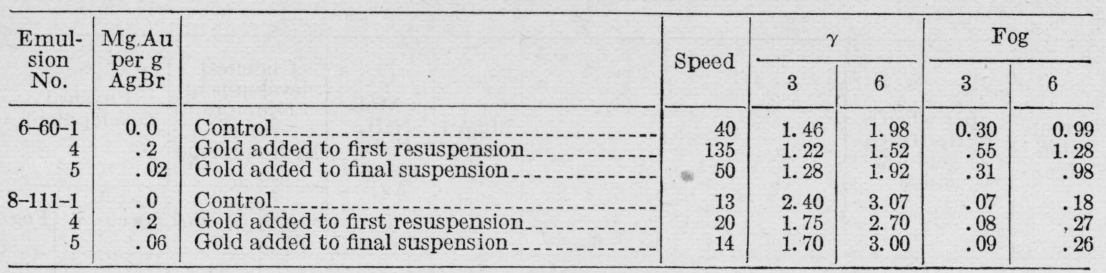

\section{SUMMARY}

1. Photographic emulsions, after ripening and washing, were treated with gelatin-protected sols of silver iodide, silver sulphide, metallic silver and metallic gold, under such conditions that the control and treated portions might be expected to differ only in the presence of particles of the colloid adsorbed to the silver halide grains of the latter, with the object of thus introducing sensitivity nuclei. Results were improved by the use of deactivated gelatin, to reduce nucleation prior to the addition of the colloid.

2. Gelatin emulsions with excess silver salts may be developed normally, if the excess silver is reduced to a concentration of the order of the excess bromide in a normal washed emulsion, and if the hydrogen ion concentration is maintained at a sufficiently high value after the introduction of the excess silver. The grains of these emulsions carry a positive charge, and they are particularly adapted to sensitization by the negatively charged metallic colloids.

3. The effects produced by the silver iodide, and by the two metallic colloids, differ in type and in probable cause. The results with colloidal silver sulphide were negative. All the colloids retarded afterripening to such an extent that the practical effect, when the emulsion was digested after washing, was desensitization.

4. Colloidal silver iodide produced a marked increase in contrast with chemical development of the emulsion; the immediate effect, without after-ripening, was an increase in density for the longer exposures. Using physical development, there was a great increase in speed. Both these effects may be explained by acceleration of development, and this is most probably to be attributed to increased adsorption of the developer, since the conditions exclude the possibility of nucleus exposure.

5. Colloidal gold and silver increased the speed of emulsions with excess silver. The effect was most pronounced in the underexposure region, and bears no resemblance to an acceleration of development. The evidence is that these materials can not increase the photochemical sensitivity of the emulsions by reacting with bromine liberated in the photolysis of silver bromide. The results are readily explained in terms of orientation of the photolysis at the sensitivity nucleus formed by the colloidal particle.

Washington, May 29, 1928. 